\title{
Chapter 14 \\ Doing Digital Migration Studies: \\ Methodological Considerations \\ for an Emerging Research Focus
}

\author{
Koen Leurs and Madhuri Prabhakar
}

\subsection{Introduction: Researching Migration in the Digital Era}

"Electronic mediation and mass migration mark the world of the present"; this diagnosis was reached by Arjun Appadurai two decades ago (1996, p. 4). In Europe and beyond, this observation has only gained further pertinence. Media and communication technologies have historically played a crucial role in the lives of migrants. It is well documented how migrants have historically maintained transnational networks through letters, newspapers, radio, satellite television and the telephone. However, in recent years, both the scale and types of migration and digital networking have drastically changed (e.g. Georgiou 2006; Madianou and Miller 2012). While migration remains one of the most challenging life experiences one could face - which technology cannot magically solve -, the increasing global adoption of information and communication technologies (ICTs) has altered a variety of migration dynamics. This transformation is twofold. It includes a growing reliance on digital technologies for top-down governmental border control, surveillance and migration management by state authorities. Secondly, smart phones, social media platforms and apps are used by migrants as new channels to access information, resources and news; for purposes including communication, emotion-management, intercultural relations, identification, participation, political protest and sending/ receiving remittances. The rapid developments in migration that happen in conjunction with the spread of ICTs raise considerable theoretical, methodological and ethical challenges. Hence, in this chapter, we focus particularly on methodological concerns in the emerging research focus of digital migration studies.

The growth of migration and ICTs are unprecedented and the two increasingly affect one another. While the number of expatriates is estimated to have reached

K. Leurs $(\bowtie) \cdot$ M. Prabhakar

Utrecht University, Utrecht, The Netherlands

e-mail: K.H.A.Leurs@uu.nl; m.prabhakar@uu.nl

R. Zapata-Barrero, E. Yalaz (eds.), Qualitative Research in European Migration

Studies, IMISCOE Research Series,

https://doi.org/10.1007/978-3-319-76861-8_14 
56.8 million by the end of 2017 (Finaccord 2014), globally, over 65 million people were forcibly displaced in 2015 (UNHCR 2016). Both voluntary and forced migrants are increasingly digitally "connected migrants" (Diminescu 2008), who live in one place, but use mobile devices and social media platforms to conduct their lives across the world. While e-passports, iris scans and on-board airplane wireless internet facilitate the lifestyle of the global elites zipping in and out of Europe, for 'irregularized migrants' Europe remains the deadliest destination in the world. In 2015, over one million people reached Europe by sea, while an estimated 3784 people died. Even worse after the closure of the Aegean route, in 2016, alongside 387.895 sea arrivals, 5143 people died/went missing. Indeed, with 186.768 arrivals and 3116 deaths/missing persons in 2017, the route most people are currently taking from Libya to Italy, is more expensive and risky than the route from Turkey to Greece (IOM 2018). Nearly 2000 official entry ports and 60,000 km of land and sea borders are increasingly managed through digital technologies, and 'irregular migrants', for example, experience 'smart borders' entirely differently from expats. At the Mediterranean Sea, their phone signals may be traced by drones and satellites that are part of the European Border Surveillance System (Eurosur). Upon arrival, they may be coerced to have their fingerprints scanned so that an algorithm can decide upon their futures on the basis of the European Dactyloscopy (EURODAC) biometric database (Leurs and Shepherd 2017).

Alongside connected migrants, recent buzzwords including "e-diasporas" (Diminescu 2008), "mediatized migrants" (Hepp et al. 2011), refugees' "information precarity" (Wall et al. 2015), "digital diasporas" (Everett 2009), "smart refugees" (Dekker et al. 2017), "digital deportability" (Trimikliniotis et al. 2015) and migrant "polymedia" (Madianou and Miller 2012) signal the emergence of a new research focus which can be labelled as digital migration studies. This chapter aims to contribute to this research area by offering methodological considerations to qualitatively study migration in, through and by means of the internet. There is need for such an intervention that spans the field of migration, anthropology, sociology, geography, media and communication studies. Although there is growing attention for migration and ICTs, a general "paucity of research" on the topic remains (McGregor and Siegel 2013, p. 2), this area is particularly "under-researched" in the field of migration studies (Oiarzabal and Reips 2012, p. 1334). In media and communication studies, the impact of ICTs on migrants in Europe also remains relatively uncharted (Ponzanesi and Leurs 2014; Leurs and Ponzanesi 2018). These gaps urgently need to be addressed, as the "information migration society" may offer new opportunities, but also constructs a "new distribution of power" (Borkert et al. 2009, pp. 32-33), particularly in the context of forced migration and digital connectivity (Leurs and Smets 2018).

For example, the UNCHR estimates over two-thirds of refugee households living in urban settings - which is the case for most forced migrants in Europe - have access to an internet enabled phone (2016, p. 14). Across Europe, Syrians have set up Facebook groups and pages that arguably function as a 'Trip advisor for refugees'. Facebook pages like 'هنا هولندا' (Syrians Netherlands, nearly 82.000 likes) and Facebook groups 'البيت السورين 'German Syrisches Haus, 44.000 likes) and 'دiberal Syrians guide Sweden, 11.000 members) are digital diaspora communities that could be of significant importance for 
discounting rumours, informal language learning, and interacting with fellow members of the host society (Dekker et al. 2018). However, there is little reflection and empirical study of how such digital practices may facilitate possible socializing, integration, bonding and bridging capital, empowerment through amplification of their voices, information needs, or could result in possible disempowerment, isolation or segregation.

While literature on forced migration and ICTs in particular is scarce, publications reflecting on methodologies of studying connected migrants are virtually nonexistent. Indeed, while notions such as digital and e-diaspora are increasingly strongly theorized, "much less literature addresses methodological issues in diaspora research, particularly in the field of media and communication" (Smets 2018). Therefore, this chapter offers reflection on how we can do digital migration studies. We advocate a social justice perspective, which means we recognize the importance of critical theory and empirical data to document and challenge unjust power relations. As an emancipatory starting point, we seek to acknowledge "migrants are digital agents of change" (Borkert et al. 2018). Although digital divides alongside axis of geography, gender, age, class, race, nationality, and generation persist and unevenly shape access, ownership and use, attention for the situated everyday experiences of migrants is vital to bring about societal change. Digital migration researchers are, for example, well equipped to counter dominant stereotypes that portray refugees as culturally handicapped and unable to handle advanced technologies (O’Malley 2015).

Intended as an introduction to an emerging field, this chapter provides an extensive bibliography spanning across varying disciplines. As a red thread, we focus our discussion on methods for doing digital research on migration in Europe that may accommodate a commitment to social justice. Both in working with elite migrants and with marginalized communities such as refugees, we believe there is no future for digital migration studies that is inattentive to offline/online power hierarchies. Our argument is structured as follows: below, we first offer a statement of the emerging research area. Drawing on Candidatu et al. (2018), we have mapped the field by distinguishing between three paradigms (1) migrants in cyberspace; (2) everyday digital migrant life; (3) migrants as data. Doing digital migration research requires scholars to synthesize methods used in these three paradigms. We offer suggestions on how to do so by discussing the methodological research principles of relationality, adaptability and ethics-of-care.

\subsection{Digital Migration Studies: 3 Paradigms}

Digital migration studies encompass work conducted across media, cultural and communication studies, internet studies, information studies, migration studies, ethnic, diaspora and racial studies, transnationalism, gender and postcolonial studies, anthropology, development studies, geography, border studies, urban studies, human-computer interaction, science and technology studies, law and human rights. Digital migration studies have been influenced by evolving scholarly perspectives, 
foci and accompanying methodologies and tools, as we discuss in greater detail elsewhere (Candidatu et al. 2018). Variations reflect developments in the broader field of internet studies (see Table 14.1). The three paradigms of digital migration studies we discern are (1) migrants in cyberspace; (2) everyday digital migrant life; (3) migrants as data.

These three paradigms display varying degrees of centring digital technologies as the main object of their studies, what can be called "digital-media-centric-ness" (Pink et al. 2016a, pp. 9-11). The critique of media-centrism alerts us to the degree in which specific technologies, platforms or devices are foregrounded or decentered. We argue technologies can never be considered as inseparable from other

Table 14.1 Digital migration studies paradigms

\begin{tabular}{|c|c|c|c|c|c|}
\hline Paradigms & $\begin{array}{l}\text { Exemplary } \\
\text { studies }\end{array}$ & $\begin{array}{l}\text { Theoretical } \\
\text { frameworks }\end{array}$ & $\begin{array}{l}\text { Methodological } \\
\text { approaches }\end{array}$ & Merits & Critiques \\
\hline \multirow{5}{*}{$\begin{array}{l}\text { I. Digital- } \\
\text { media-centric } \\
\text { cyber culture } \\
\text { studies } \\
\text { approach: } \\
\text { migrants in } \\
\text { cyberspace }\end{array}$} & $\begin{array}{l}\text { Markham } \\
(1998)\end{array}$ & Cyberspace & \multirow{5}{*}{$\begin{array}{l}\text { Humanities/ } \\
\text { hermeneutical } \\
\text { methods } \\
\text { including } \\
\text { discourse } \\
\text { analysis, but also } \\
\text { virtual } \\
\text { ethnography }\end{array}$} & \multirow{5}{*}{$\begin{array}{l}\text { Pioneering, } \\
\text { agenda- } \\
\text { setting, } \\
\text { development } \\
\text { of virtual } \\
\text { ethnography } \\
\text { and cyber- } \\
\text { research } \\
\text { ethics }\end{array}$} & \multirow{5}{*}{$\begin{array}{l}\text { Utopian, } \\
\text { celebratory, } \\
\text { lacking } \\
\text { contextual } \\
\text { awareness }\end{array}$} \\
\hline & $\begin{array}{l}\text { Gajjala } \\
(2004)\end{array}$ & Cyber culture & & & \\
\hline & $\begin{array}{l}\text { Everett } \\
(2009)\end{array}$ & \multirow[t]{3}{*}{$\begin{array}{l}\text { Cyber } \\
\text { communities }\end{array}$} & & & \\
\hline & \begin{tabular}{|l|} 
Bernal \\
$(2014)$
\end{tabular} & & & & \\
\hline & $\begin{array}{l}\text { Frouws } \\
\text { et al. (2016) }\end{array}$ & & & & \\
\hline \multirow{4}{*}{$\begin{array}{l}\text { II. Non- } \\
\text { digital-media- } \\
\text { centric } \\
\text { ethnographic } \\
\text { approach: } \\
\text { everyday } \\
\text { digital } \\
\text { migrant life- }\end{array}$} & $\begin{array}{l}\text { Miller and } \\
\text { Slater } \\
(2000)\end{array}$ & $\begin{array}{l}\text { Mediation and } \\
\text { mediatization }\end{array}$ & \multirow{4}{*}{$\begin{array}{l}\text { Social science } \\
\text { methods } \\
\text { pre-existing the } \\
\text { internet: e.g. } \\
\text { Ethnography, } \\
\text { participant } \\
\text { observation, } \\
\text { interviewing }\end{array}$} & \multirow{4}{*}{$\begin{array}{l}\text { Context- } \\
\text { sensitivity: } \\
\text { Material, } \\
\text { social, } \\
\text { symbolic, } \\
\text { economic and } \\
\text { emotional } \\
\text { awareness }\end{array}$} & \multirow[t]{4}{*}{$\begin{array}{l}\text { Descriptive, } \\
\text { small scale, } \\
\text { particularistic }\end{array}$} \\
\hline & $\begin{array}{l}\text { Georgiou } \\
(2006)\end{array}$ & $\begin{array}{l}\text { Everyday } \\
\text { practices }\end{array}$ & & & \\
\hline & $\begin{array}{l}\text { Madianou } \\
\text { and Miller } \\
(2012)\end{array}$ & \multirow[t]{2}{*}{$\begin{array}{l}\text { Offline } \\
\text { embedded } \\
\text { online }\end{array}$} & & & \\
\hline & $\begin{array}{l}\text { Zijlstra and } \\
\text { Van Liempt } \\
(2017)\end{array}$ & & & & \\
\hline \multirow{4}{*}{$\begin{array}{l}\text { III. Digital- } \\
\text { media-centric } \\
\text { digital } \\
\text { approach: } \\
\text { migrants as } \\
\text { data }\end{array}$} & $\begin{array}{l}\text { Diminescu } \\
(2008)\end{array}$ & \multirow{4}{*}{$\begin{array}{l}\text { Actor-network } \\
\text { theory, new } \\
\text { materialism, } \\
\text { posthumanism }\end{array}$} & \multirow{4}{*}{$\begin{array}{l}\text { Digital methods; } \\
\text { 'born digitally' } \\
\text { data-driven } \\
\text { approaches }\end{array}$} & \multirow{4}{*}{$\begin{array}{l}\text { Data-driven, } \\
\text { medium- } \\
\text { specificity, } \\
\text { cross- } \\
\text { platform } \\
\text { analysis }\end{array}$} & \multirow{4}{*}{$\begin{array}{l}\text { Flat ontology, } \\
\text { lack of } \\
\text { emancipatory } \\
\text { ideals; ethical } \\
\text { questions and } \\
\text { privacy } \\
\text { concerns }\end{array}$} \\
\hline & $\begin{array}{l}\text { Kok and } \\
\text { Rogers } \\
(2017)\end{array}$ & & & & \\
\hline & $\begin{array}{l}\text { Messias } \\
\text { et al. (2016) }\end{array}$ & & & & \\
\hline & $\begin{array}{l}\text { Sharma } \\
\text { and } \\
\text { Booker } \\
(2017)\end{array}$ & & & & \\
\hline
\end{tabular}

Adapted from Candidatu et al. (2018) 
(offline) material, historical, emotional and contextual factors. The three paradigms mapped above co-exist simultaneously and single studies can draw on multiple paradigms.

\subsubsection{Paradigm (I) Migrants in Cyberspace}

Internet studies came of age with a digital-media-centric focus on cyber space communities in the 1990s. This paradigm approached - the by then largely text-based cyberspace as a distinctive virtual space. Drawing especially from humanistic and hermeneutical interpretative techniques, researchers theorized how people were able to leave their physical bodies behind and experiment with their gender, racial and national identity somewhat irrespective of their situation in the offline world. Illustratively, in her 1998 book Life online: Researching real experience in virtual space, Markham reflects on the sense of identity, presence and community that people establish online through written text-based interactions. Importantly, Markham quickly realized it was unethical to only be a "distanced observer" of how "others" interacted in virtual spaces from her comfortable position behind her screen (1998, pp. 24-25).

Scholars interested in migration and diaspora further developed this paradigm by raising greater awareness of how offline cultural differences are similarly manifested online. In the early 1990s, Gajjala initiated research on the "cyborg diaspora" of the South Asian Women email list (SAWnet). Gajjala participated herself, but over time also announced to fellow participants she was researching the mailing list as part of her dissertation work. This declaration lead to heavy debates, protest and refusals to be researched by some list posters, reminding us of the intricate researcher-researched relationships that also exist online (Gajjala 2004, pp. 19-28). Bernal's long-term observation of content posted on Eritrean portal and discussion websites like Dehai.org, Asmarino.com and Awate.com documents how users imagine belonging to fellow users in diasporic communities (2014). She argues how people in the diaspora form an "online public sphere" and through "infopolitics" protest violence and repression by the Eritrean state (2014, pp. 8-9).

In their recent study, Frouws et al. (2016) take a virtual ethnography approach to observe the use of social media among migrants and refugees from the Middle East and from the Horn of Africa who are heading for Europe. They draw from Arabic and Somali language internet searches conducted on platforms including Facebook, Twitter and YouTube in 2015 and 2016, using various keywords to find postings around the topic of irregular migration, such as 'Tahriib' in Somali. Based on a discourse analysis, they look for recurring themes in order to present a typology of ICT used along mixed migration routes which they support with screenshots of posts they located on Facebook groups, Tweets and YouTube channels. In sum, this pioneering paradigm innovatively foregrounds the digital cultural production of migrants. Additionally, although the term cyber has gone out of fashion scholars in this area continue to raise attention for the construction of digital identities and further developed virtual ethnography and cyber-ethical research practice. 


\subsubsection{Paradigm (II) Everyday Digital Migrant Life}

In contrast with the first paradigm, the second paradigm is non-digital-media-centric as it takes online-offline relationships as its main unit of analysis. Rather than taking digital practices as a starting point, in this strand scholars combine fieldwork in physical places with observing digitally mediated practices. In their study on internet use among Trinidadians, Miller and Slater famously note "if you want to get to the Internet, don't start from there" (2000, p. 5). Instead, they conducted ethnographic work on topics ranging from sex, religion and commerce to personal relations in diverse settings, including cybercafés, businesses, middle-class houses and squats in Trinidad, as well as websites, e-mail and chat sites frequented by Trinidadians living abroad. Through semi-structured interviews, unstructured discussions and observation in café's, clubs, schools and community centres in New York and London, and by collecting visual media materials, Georgiou explored the role of media in the diasporic identity construction of Greek-Cypriots. She shows that media consumption of migrants can only be understood in its broader social, spatial and temporal context as part of everyday spaces including domestic, public, urban and transnational connections (2006). Madianou and Miller (2012) took a similar multi-sited ethnography approach in their study of the role of mediation during prolonged separation between Filipino mothers in London and Cambridge and their children living in Manila and elsewhere in the Philippines. Observing and interviewing mothers and children in the UK and the Philippines, they advocate that acknowledging the "human context for media use" is essential to understanding the mediated relationships between migrant women engaged in "distant mothering" of their "left-behind children" (Madianou and Miller 2012, pp. 2-3). Recently, research approaches aiming to understand digital mediation as a feature of material and embodied lived experiences, practices and our broader social worlds, are further developed as distinct methodological apparatuses, including "digital ethnography" (Pink et al. 2016a) and "digital sociologies" (Gregory et al. 2017). These initiatives seek to flesh out qualitative internet research methodologies that acknowledge that "no one lives an entirely digital life" (Miller and Horst 2012, p. 16) and technologies, media and the internet do not exist in isolation from, but shape and are shaped by everyday social life. In this spirit, Zijlstra and van Liempt (2017) drew on trajectory ethnography to study the use of smartphones among Afghan, Iranian and Syrian migrants during their border crossings and travels from Greece and Turkey onwards to Netherlands, Germany, Sweden and elsewhere in Europe. They update the mobile method of trajectory ethnography by following informants through a combination of offline and digital observations through time. From this paradigm, we learn that digital migration studies scholars should approach contemporary migrant experiences of communication and mediation as situated in distinctive power-ridden social, cultural, historically and localized settings. 


\subsubsection{Paradigm (III) Migrants As Data}

Migrants are increasingly datafied (Leurs and Shepherd 2017). As an example of a conservative or reactionary approach to digital migration, European governments aiming to manage migration top-down are increasingly tapping into big data; not only are biometric databases augmented and interconnected with the aim of more efficient border control, authorities also scrape and analyse social media data to predict migrant flows and circulate specifically targeted deterrent information campaigns (Broeders and Dijstelbloem 2013). Internet researchers are also critically exploring the "datafied society" through engaging with new possibilities for "studying culture through data" (Van Es and Schäfer 2017). The turn towards data-driven research and digital, computational methods is accompanied by a return to digitalmedia-centric understandings of the Internet. In terms of data collection, this has led to a shift where researchers, in the words of Rogers, "follow the medium" (2013, p. 24) and repurpose computing techniques as research tools - such as the ones developed at the University of Amsterdam's Digital Methods Initiative ${ }^{1}$ - to "diagnose cultural change and societal conditions by means of the Internet" (Rogers 2013, p. 21).

Media and migration scholars have used computational methods including issue mapping, hyperlink and network analysis to study digital migrant connectivity. Diminescu's pioneering e-Diasporas Atlas $^{2}$ project consists of a longitudinal mapping of 27 e-diasporas and 8.000 migrant websites (Diminescu 2008). Alongside building the important open-source network visualization tool Gephi, ${ }^{3}$ they offer interactive graphical visualizations of the corpus, in addition to archiving raw qualitative empirical open data such as texts, videos, interviews gathered in the research. Kok and Rogers (2017) queried local domain search engines (google.co.uk, .nl, co.ke, .se, .dk, .no, .ca and .com) for Somali diaspora related keywords and imported search results in IssueCrawler, a network visualization tool. ${ }^{4}$ They also queried Facebook in the search box for pages of self-identifying Somali groups, the search result pages were "liked" in order to be able to extract data from these pages using the Facebook research tool Netvizz..$^{5}$ On the basis of scraped data, they argue that digital practices of Somalis in the diaspora operate as a new multi-territorial process of "transglocalization" (Kok and Rogers 2017, p. 23). Messias et al. similarly draw on quantitative pattern detection of web data, in this case the "places lived" section of 22,578,898 geo-coded Google+ social media profiles to develop "new theories of international migration" (Messias et al. 2016). In their study of racist and antiimmigrant posts on Twitter, Sharma and Brooker deploy the concept of "assemblage" to untangle relations between "human (social media users), social phenomena (race

\footnotetext{
${ }^{1}$ http://digitalmethods.net/

${ }^{2} \mathrm{http}: / /$ www.e-diasporas.fr/

${ }^{3}$ https://gephi.org/

${ }^{4} \mathrm{https}: / /$ www.issuecrawler.net/

${ }^{5} \mathrm{https}: / /$ apps.facebook.com/netvizz/
} 
and racism) and the non-human (digital technologies and devices)" (Sharma and Booker 2017, p. 464). They draw on the methodological device of Chorus, ${ }^{6}$ a tool developed to carry out social science research with Twitter data (Brooker et al. 2016).

In sum, this paradigm invites migration researchers to consider drawing on new tools and techniques to gather computational data generated by users. From this paradigm, we also learn that digital practices take place in distinctive digital settings: we need to be attentive to medium-specificity: what are the affordances, norms and usages of Facebook and how do they differ from platforms like Twitter, Instagram, blogs, and discussion forums? Having mapped digital migration studies into three paradigms, below we reflect upon how to do digital migration studies in practice. For this purpose, we draw on our social justice oriented model to propose the research principles of relationality, adaptability and ethics-of-care. These principles offer guidelines to operationalize the paradigms of migrants in cyberspace, everyday digital migrant life and migrants as data respectively.

\section{Relationality}

Publications on media and migration commonly offer snapshots that fix the dynamic process of digital diaspora formation in time and space. However, local intercultural relations and transnational diaspora formation are always in process. Connected migrants are situated across online and offline contexts, spanning here and there, across platforms, communities and borders, at the intersections of enabling and constraining power relations shaped by nationalism, race, gender, age, class and religion (Leurs and Ponzanesi 2018). In response to paradigm 1 (migrants in cyberspace), we propose relationality as a first principle to achieve greater sensitivity in our research for how practices of migrant connectivity are often paradoxical, and always processual and interlinked.

Digital migration studies scholars should take into account the specificity of digital mediation while approaching it as inherently related to broader human processes. Conceptually, the "M.E.A.L.S" theoretical touchstones are helpful to develop this principle further (Losh 2015): rather than transcendental, digital technologies are material; rather than disembodied, digital technologies are actively embodied; rather than neutral, technology use solicits affective responses; rather than efficient and labour saving, digital technologies involve labour; rather than universal, digital technologies are distinctly situated. Specifically in the case of migrants, a dialectical understanding of the relationship between people and digitality draws our attention to how connected migrants are always involved in a continuum of simultaneous processes of "encapsulation" - maintaining a sense of collective identity with fellow members of a bounded diasporic community - and "cosmopolitanism" - bridging local intercultural differences by engaging with various communities different to their own (Christensen and Jansson 2014). Starkly put, migration scholars commonly focus on transnationalism, whereas, for example,

\footnotetext{
${ }^{6} \mathrm{http}: / /$ chorusanalytics.co.uk/
} 
geographers, ethnic, racial and urban studies scholars study local cosmopolitanisms. However, it is urgent to combine attention for transnationalism with sensitivity to how migrants relate to local cultural diversity (Leurs and Ponzanesi 2018). In methodological terms, the relationality principle may be operationalized through combining qualitative and quantitative data; multi-sited and multi-temporal ethnographic research, taking, for example, different physical locations as possible entrypoints, in combination with research across digital platforms.

First, an example of a relational approach to combining qualitative and quantitative data: for their seminal Mapping Refugee Media Journeys project, Gillespie et al. (2016) conducted interviews with Syrian and Iraqi refugees about their social media and smartphone use along their journeys to Europe, and combined these findings with quantitative social network analysis of Facebook groups and Twitter networks. Second, an example of how to account for how digital migration may revolve around both agency and disempowerment: studies commonly champion how diasporas tap into ICTs to digitally challenge home-country regimes by voicing concerns, financing advocacy groups, challenging human right records and documenting atrocities (e.g. Koinova 2010). However, researchers have to account for complexities and contradictions through non-digital-media-centric-ness. ICTs not only offer tools for contestation, but recent research by Moss shows authoritarianism is also a networked force of "digitally-enabled transnational repression": for example, in the case of the Syrian diaspora, anti-regime activists who fled to the US and the UK experience "networked authoritarianism" and feel they have to censor themselves online as a result of the digital presence of pro-Assad-regime (Moss 2016, p. 13). To detail experiences among migrants, Moss conducted Skype and offline face-to-face interviews with transnational activists about their experiences of state oppression before and after migration, and their decision to publicly identify as activists using ICTs or not.

Third, a relational approach to study across time and space is non-linear and comparative: for example Donà initiated a study on Rwandans in London, which she expanded to Brussels, Togo and Uganda (2014). In Rwanda, she observed dynamics at government-sponsored ingando (solidarity camps) and "itorero" (cultural schools). Additionally, she engaged in what she terms "netnographic e-transnationalism" by observing postings and comments on sites and Facebook pages of initiatives like Rwandan Youth for Change (RY4C), the Rwanda Youth Patriots/UK and the Rwandan Youth Information Community Organization (rYico. org). Fourth, a relational approach to offline and online dynamics is exemplified in Zijlstra and Van Liempt's trajectory ethnography: starting from Europe's borderlands towards North-Western Europe, they combined interviews, offline and online observations of border crossings and onward journeys of irregular migrants (2017). Fifth, a relational networked understanding of stakeholders that shape migrant connectivity is important. For example, Gordano Peile studies the political economy of migrant connectivity (2013). Drawing on in-depth interviews, she compares narratives of low income Moroccan and Ecuadorian migrants with narratives of marketing spokespersons of five telecom providers that target migrant customers. Finally, a relational approach that acknowledges the affordances of various media platforms 
is important: on the basis of in-depth interviews with Syrian asylum migrants, Dekker et al. (2018) argue that various applications and social media platforms including WhatsApp messaging, Facebook groups, Viber video-chat and navigation are used simultaneously, and they note each plays a distinct role in migration decision-making.

In sum, the relationality principle can be operationalized by combining both qualitative and quantitative data gathered through online and offline methods, working across online platforms and offline field sites, being attentive to various stakeholders in the field, and sharing attention for embodied experiences and medium-specificity as well as transnationalism and home-making.

\section{Adaptability}

In her book, Internet ethnography. Embedded, embodied and everyday, Hine concludes "If ethnographer for the internet is not the sexiest job of the twenty-first century, according to Harvard Business Review, it is at least a challenging one in terms of the range of skills and level of adaptability required" (Hine 2015, p. 189, our emphasis). Adaptability is particularly strongly needed for digital migration research. As a way to operationalize paradigm 2, i.e. "everyday digital migrant life", we believe adaptability is required because of a combination of unstable factors: (1) the ever-changing population of expat and forced migrants; (2) their means and routes of migration; (3) shifting policies and practices devised to control migration, in combination with (4) an ever changing ICT and social media landscape and (5) continuously changing (digital) methods. A high degree of flexibility is required for researchers to be open towards following people and phenomena across locations and platforms and be receptive to unexpected outcomes and insights. Therefore, room for adaptability needs to be built into digital migration studies research designs. Being attentive to user practices across preferred platforms, digital migration researchers constantly need to learn to become competent users of new digital environments. From "newbie" to a platform, there will be a period one needs to familiarize oneself with the technical terms and conventions. We will make mistakes and we will be reprimanded for it by fellow users and communities. However, it is important to write about such experiences and to make those processes generative for a social justice oriented politics of knowledge production.

How can we ensure a degree of flexibility in our research design? It has proven to be effective to draw on approaches that allow participants to research, share and map out their own media use practices. For example, Hepp et al. (2011) operationalized their study of the German Moroccan, Russian and Turkish diaspora by collecting empirical data in Berlin and Bremen. Working with members of each diaspora, they focused on everyday media use patterns. For this purpose, they engaged in semi-structured interviews and asked participants about their experiences of migration, identity formation and media use. They triangulated interviews with techniques that warrant a degree of adaptability: (1) network maps: pencil and paper drawings of individual communicative networks; (2) two-week media diaries and (3) materials shared by informants and photographs of private and public media use locations (2011). 


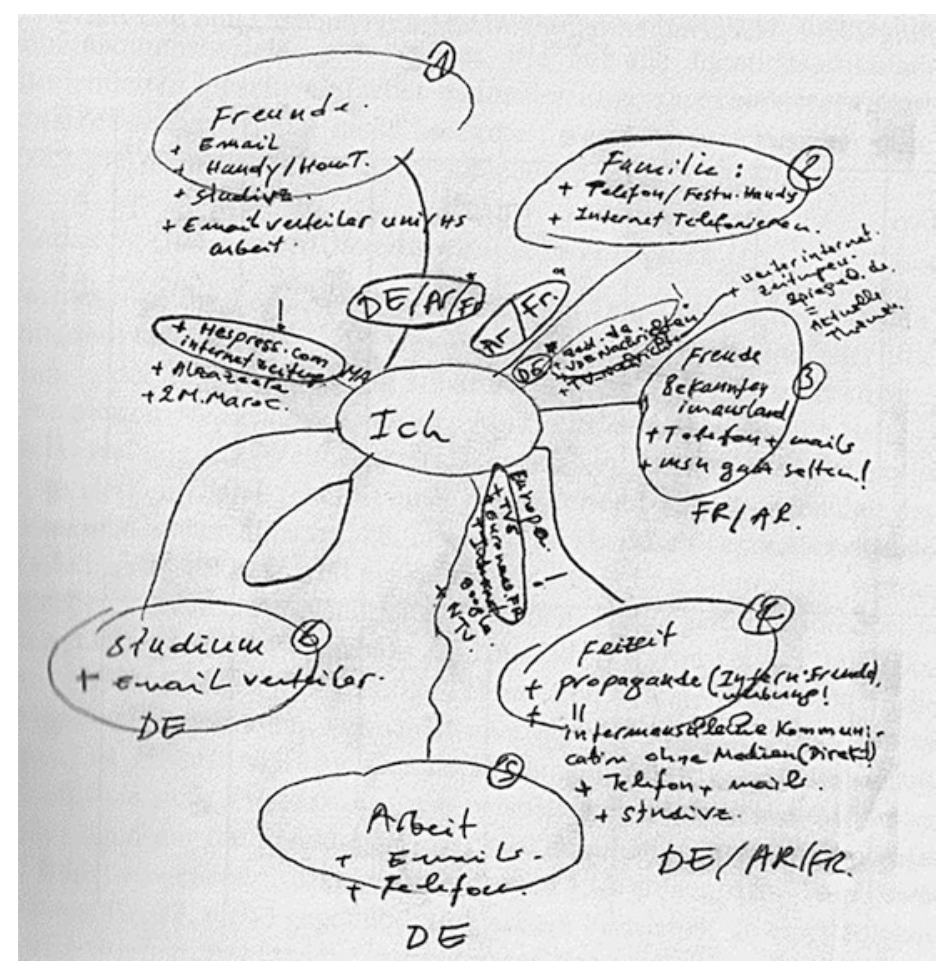

Fig. 14.1 Network map Ilias, 11 December 2008 (Hepp et al. 2011, p. 227)

For example, Fig. 14.1 shows the ego network map of Ilias, a 28-year-old Moroccan-German young man. Through the mapping exercise, we get insight about the following connectivity practices. He (1) combines e-mail and his mobile phone to connect with his friends in German, Arabic and French; (2) uses Arabic and French to speak over the phone and voice-over-IP chat (Skype) with family; (3) uses phone, e-mails and instant messaging with friends living in the diaspora; (4) combines German, Arabic and French to consume entertainment; (5-6) uses German while calling and e-mailing at work and at university. Such descriptive hand-drawn maps can be quite useful in characterizing the various roles connected migrants play, including assessing opportunities and constraints, for example, by exploring what resources including "economic", "social" or "cultural capital" (Bourdieu 1986) they can and cannot access. The maps inform us about the degree of encapsulation within the Moroccan diaspora in Germany and abroad, alongside processes of cosmopolitanization as we see how Ilias bridges across difference at the local and national level.

Contact lists - for example, on a mobile phone or social media friend lists, can also be used to initiate network mapping exercises. They provide input to conduct a qualitative ego-network analysis (researching the nodes in the network to whom ego is connected). For example, to understand the meaning of the mobile phones in 
everyday lives in rural and urban Jamaica, Horst and Miller asked research participants to share their phone contact list and used it to elicit responses. They invited informants to share details for each contact, including the kind of relationship, the frequency of calls and messages, when they last spoke and what they talked about (2005). The first author of the present chapter created ego-network diagrams based on Facebook friendship networks (Leurs 2017). In a study with a diverse group of young Londoners from working, middle and upper-middle class families, he visualized the friendship networks of those young people who had a Facebook account. During face-to-face interviews, he would visualize the networks together with informants using the commercial but freely accessible Facebook application TouchGraph Facebook Friend Graph. Research participants were asked to login and open the Touchgraph application. Then, the application's algorithm searched for degrees of similarities between groups of friends, and colour coded befriended Facebook contacts who shared similar Facebook user practices into clusters.

Figure 14.2 shows the Facebook friendship visualization of Gabriel, a 15-yearold girl "originally from Malawi", who had been living in London for 2 years with her mum who is employed as a nanny. The diagram does not indicate on the basis of what kind of similarities clusters were formed, therefore, visualizations lend themselves very well to have informants research their own networking practices. This way, the friendship network visualizations are useful to elicit reflections of transnational, national and local networking practices. The top two clusters and upper right cluster are school friends in London, which triggered her reflection on

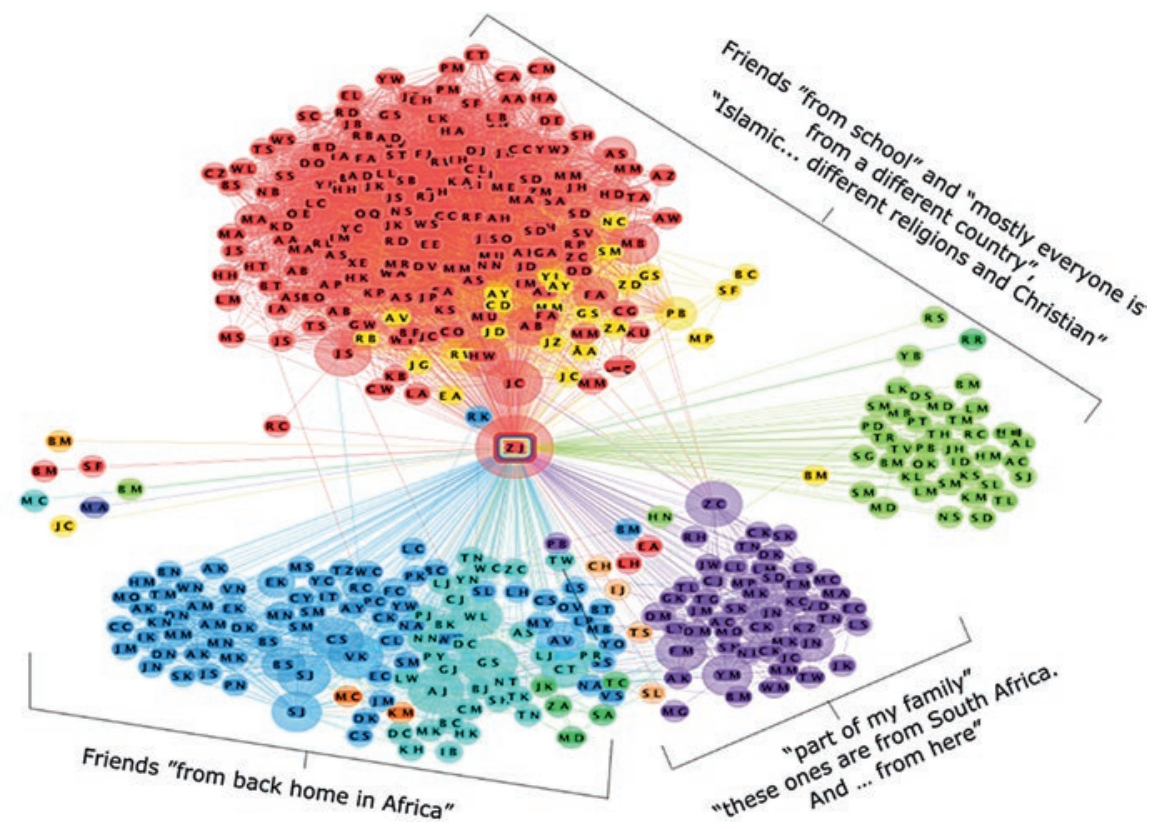

Fig. 14.2 Facebook friendship visualization Gabriel, 15-year-old 
the multi-racial composition of her neighbourhood and school. The cluster at the bottom right involves family in London and her dad and sisters who live in Malawi and South Africa. "It's kind of like living in one mode and then the other people living in another world and there's a big huge gap between those two worlds". Using Skype, Viber, WhatsApp and Facebook, she remains in touch, she reflects: "it kind of feels like you're in their world and you can finally see them and talk to them and hear their voices and everything so it's quiet really good". The two clusters at the bottom left were also important: "the whole African continent I have friends there. Places like Madagascar, Mauritius, you know the islands and everything". Transnational connectivity not only revolves around Skype, e-mail or calling. Gabriel, for example, also plays multi-player games using her X-Box console with friends living locally as well as in South Africa and Malawi, if the connection is good ("if it connects sometimes, because sometimes it doesn't and sometimes it does"). This last empirical example indicates that in a "polymedia" environment (Madianou and Miller 2012), an array of platforms with distinct medium-specific affordances are appropriated for often unintended uses. Therefore, it is highly unlikely to envision all possible digital practices prior to engaging in empirical qualitative fieldwork and we recommend digital migration researchers to dare to leave room for unexpected results.

\section{Ethics-of-Care}

In response to paradigm 3 (migrants as data), we insist digital migration studies demand a thorough reconsideration of research ethics. For example, as digital practices are increasingly understood through the lens of data, computational approaches are commonly idealized. Big Data, as the new privileged mode of knowledge production, elevates quantitative over qualitative data approaches. For example, Halfpenny and Proctor (2015) elaborate the ways in which "e-methods" and "e-research" connote both "electronic", but also "enhanced" research methods. Before accepting the "objectivity" of Big Data methods and datafication, one must keep in mind that data based technology and human experience are mutually constituted. "E-methods" and "e-research" methods are always culturally mediated methods and are not devoid of different forms of cultural prejudices and discriminations, for example, visible in the choices researchers make, and the tools that do the data scraping, cleaning, sorting and analysis in one way rather than another. Although the promise of unobtrusive observation and, for that matter, "Big" data collection, makes us believe otherwise, knowledge production about digital practices is always already distinctly situated, partial and shaped by prior frameworks and knowledge.

Especially for digital migration studies scholars, the faith in quantification to accurately represent and predict the movements of population groups, for example, should be questioned, particularly given the colonial knowledge systems based on metrics that rationalized the existence of inferior races and territories that could be ruled, dominated and exploited. In this light, digital technologies and data are increasingly used as new modes of surveillance, migration management and border 
control. For instance, in their study of "digital deportability", Trimikliniotis et al. reflect on how migrants perceive, negotiate with and resist the European Dactyloscopy (EuroDac) fingerprint database. Their ethnographic field involves digital networks and offices and camps across the Istanbul, Nicosia and Athens border triangle (2015). As social justice oriented digital migration studies scholars, we should therefore be attentive to everyday experiences and be "concerned first with social problems (social inequalities, race, gender) and then with technology" (Gregory et al. 2017, p. xxi). We argue that computational methods, especially when deployed uncritically, are incompatible with researching marginalized and vulnerable groups including migrant populations.

A first reason is because qualitative researchers commonly accept that people's awareness, understanding, trust and consent to participate are prerequisites for conducting research (see Chap. 15 by Van Liempt and Bilger in this anthology). Within a mixed-methods setup, when (participant-)online observations are combined, for example, with 1-1 interviews or focus-groups, individual permission can be obtained. However, while doing digital migration studies, awareness and consent could fall into a grey zone. For example, research based on virtual ethnographic methods runs this risk. Scholars interested in digital-media-centric observing and archiving interactions in a given platform could easily fall into a role of invisible 'lurker'. While doing research in the digital domain - although we realize it affects the observed dynamics -, we consider it essential to explicitly participate and make our presence as scholars known to the people we are studying. Formally, the Terms of Service (TOS) agreements that users agree to when signing up to social media platforms grant corporations and researchers permission to obtain and research personal data. However, we are convinced this cannot be equated with obtaining informed consent. Of course, in many instances, big data studies revolve around large scale pattern detection, but, in principle, often individual users can be identified in large scale data sets. For example, neither Messias et al. in their study of geo-coded Google+ profiles (2016) nor Kok and Rogers in their above-mentioned study on Somali Facebook use (2017), informed users about their data being included in a study. Whereas researchers in the first study can claim they did not directly interact with the users involved, this does not hold for Kok and Rogers, as they had to "like" Somali community groups in Facebook in order to gather Facebook data. They, however, do not discuss the ethical implications of their data gathering procedures. Readers are left wondering whether they setup a research account or used their own private Facebook account to carry out this study. Also, we do not know whether they announced their presence as researchers on these groups. In addition, as discussed in the section above, the first author made use of the Touchgraph application to make Facebook friendship diagrams with young Londoners. However, after Facebook changed its data retrieval and reuse policies and Application Programming Interface in spring 2015, Touchgraph could not be used any longer. The fleeting nature of digital platforms raises questions about our duties as researchers to be accountable, and to ensure replicability.

Qualitative researchers always engage in complex relationships with informants, as researcher-researched relationships are commonly not equally balanced, but 
hierarchical (See Chap. 6 by Iosofidis and Chap. 15 by Van Liempt and Bilger in this anthology). We, digital migration studies scholars, should remain attentive to such dynamics, even though digital methods may appear as disembodied, distanced and disengaged. To achieve a sense of reflexivity, sensitivity and accountability of our complicated position as researchers and the broader research cycle, we propose the principle of ethics-of-care. Drawing from a feminist ethics-of-care that revolves around attentiveness, responsibility and competence (Tronto 1994), we direct attention to the need of a responsive relationship between digital migration studies researchers and researched migrants and their digital practices. As mentioned above, digital platforms are also characterized by oppression and disparities pertaining to real human subjects. Ethics-of-care begins from the premise that, as humans, we are inherently responsive, relational beings and the human condition is the one of interdependence (Barnes 2012). As a researcher, one must keep that essence alive throughout the research cycle. This entails taking accountability for our research not only by taking responsibility of our research, but taking consideration of the consequences of our research on the researched subject or group (Leurs 2017, compare also with Fedyuk and Zentai, Chap. 10 in this anthology). This is particularly urgent for migrants who are subject to discrimination and racism, even more so for forced or undocumented migrants who live highly precarious lives. In mobilizing an ethics-of-care, we, digital migration researchers, do not remain disembodied, detached nor disengaged from our informants. For example, even though in theory they could hide behind their screens and engage in digital observations, Zijlstra and Van Liempt, in their work with vulnerable forced migrants, for example, shared a phone, clothes and a roof, as well as information about travel routes and destinations with their informants (2017, p. 179). There is no perfect solution to manage unequal relationships with informants, but managing expectations is of crucial importance, particularly in working with vulnerable groups. We, as researchers, should be transparent about the aims and consequences of our scholarship, and we should refrain from making promises we cannot keep.

To begin to operationalize ethics-of-care in the practice of digital migration studies, we find inspiration in this call to action by Pink and colleagues on the future of data-ethnographies:

We need to ask, amongst other things, what data futures would be preferable, and what role can we play as ethnographers in creating future alterities that acknowledge the relationship of data to the messy everyday life contexts where it is made and used. (2016b)

Alternative futures for digital migration data have recently been articulated by various consortia of journalists, researchers, and activists, for example, by combining large and small-scale databases. Alternative digital storytelling initiatives include the19MillionProject.com, that combines large scale Humanitarian data exchange with individual migrant testimonies; themigrantsfiles.com and missingmigrants. iom.int databases archiving data on deceased and missing migrants across the world. More in-depth initiatives include Massimo Sestini's attempt to annotate his aerial photography of refugee boats at the Mediterranean (which won the General News 2nd prize during Word Press Photo 2015) with personal experiences of individuals 
on those ships; Migrantvoice.org, a migrant-led initiative aimed to strengthen the voice, representation and participation of migrants in the UK and the first author's work around the smart-phone as a "personal pocket archive" (Boussaid and Boom 2016). For his research, publications and dissemination of research findings he invites participants to reflect on the content of their own smart-phone pocket archives. On connectedmigrants.sites.uu.nl, he publishes short video-portraits. In these participatory videos, young connected migrants reflect upon and curate their own pocket archives photos, videos, music playlist and app preferences. This approach is also taken up in the \#MyEscape / Meine Flucht, a 90-min documentary aired on the German Westdeutschen Rundfunk consists entirely of mobile phone footage shot by forced migrants on their way to Europe and is narrated by migrants themselves (WDR 2016).

In mobilizing ethics-of-care in our qualitative digital migration studies, key questions to consider include: are researched populations aware of being studied? Can they give consent, and can they refuse? Can they share their opinion about their own data? What are the benefits and harms of gathering, cleaning, analysing and possibly publically storing data? Can individuals be identified? What do we do when informants want to be identified or included under their own names, for example for advocacy purposes? Are populations informed about research outcomes? How can we appropriately care for research subjects by adapting our design to the personal and geopolitical context of research subjects? Should we, researchers, be content to rely on third party research tools that change constantly, or should we build our own tools? How can we ensure we draw on digital data to represent migrants not as an a-historical homogeneous group, but as a dynamic heterogeneous assemblage of people? How can we combine "big" and "small" data to render visible agency, capabilities and contradictory experiences and perspectives? What does digital migration studies for social justice looks like in practice? Do our digital migration studies document and improve precarious situations, vulnerability and subordination or do they risk exacerbating these conditions?

\subsection{Conclusions}

Digital migration studies are an emerging research focus that seek to understand the relationships between migration and digital connectivity. Together, they shape the "Janus-faced feature of our contemporary times, one necessitating the other". In the words of Naficy: "means of transportation generally take us away to other lands", while "communication media reconnect us to earlier places", but also to "new places and times", which is important to "re-imagine new possibilities" (2007, p. xiv). These two key processes of contemporary cultural globalization warrant greater scrutiny, particularly in the context of Europe. Europe appears to be crumbling down in the current moment as a result of the Brexit vote, the election of Trump in the US and travel bans for migrants from majority Muslim countries and, of course, the so-called 'European Refugee Crisis'. This is illustrated by hoaxes and 
fake news messages on these themes that serve as popular clickbait on Facebook, Twitter and Instagram. As media outlets seek to address these 'post-Truth' conditions, populist, xenophobic, islamophobic, racist and neo-nationalist rhetoric and sentiments have grown excessively across social media. Meanwhile, the number of internal and external European borders proliferates, and digital data are used for surveillance and migration management. Digital migration studies are concerned with such 'bottom-up' digitally mediated processes, such as transnational and local networking and connectivity, diaspora organizations, identity construction, radicalization, discrimination, activism, protest and solidarity. In addition, it is also concerned with 'top-down' digitally mediated processes of migrant management: border control, surveillance and control systems for population movements, and information provision for general audiences.

In this chapter, drawing on Candidatu et al. (2018), we have mapped the emerging research area of digital migration studies. We have distinguished between the following approaches: (1) migrants in cyberspace; (2) everyday digital migrant life and (3) migrants as data. This description of paradigms might indicate a linear development of the field, but publications show that the three paradigms are all currently in use and combined. In response to these three respective paradigms, we have subsequently offered three principles that migration scholars may want to be aware of when using and working on ICTs in their research designs. These are important to operationalize social-justice oriented digital migration studies projects. First, we have advocated for a perspective of relationality to emphasize that online and offline everyday migrant life experiences, as well as platforms, geographies and transnationalism/localism are interlinked. Secondly, as researchers, we should be prepared to adapt to constant changes in the technologies, practices and field sites that we are studying. Finally, as researchers, we should embrace an ethics-of-care while conducting our research, as vulnerable and precarious human subjects should have real consequences for our research. These principles for doing digital migration studies serve as reminders that the internet is not a destination where migrants can go to, rather, migrants are already always immersed in information and communication technologies with paradoxical and unexpected consequences.

\section{References}

Appadurai, A. (1996). Modernity at large. Cultural dimensions of globalization. Minneapolis: University of Minnesota Press.

Barnes, M. (2012). Care in everyday life. Bristol: Policy Press.

Bernal, V. (2014). Nation as network. Chicago: University of Chicago Press.

Borkert, M., Congolani, P., \& Premazzi, V. (2009). IMISCOE Working Paper, 27. https://ec.europa. eu/migrantintegration/index.cfm?action=media.download\&uuid=2AA0153F-BA25-73AF7C45D08C5FDBD891. Accessed 20 June 2017.

Borkert, M., Fisher, K., \& Yafi, E. (2018, Forthcoming). The best, the worst and the hardest to find: How people, mobiles and social media connect migrants in(to) Europe. In K. Leurs, \& K. Smets (Eds.), Social Media + Society Society. Special issue on Forced migration and connectivity in(to) Europe). 
Bourdieu, P. (1986). The forms of capital. In J. G. Richardson (Ed.), Handbook of theory and research for the sociology of education (pp. 241-258). New York: Greenwood.

Boussaid, Y., \& Boom, B. (2016). Het 'broekzakarchief'. Delen is het nieuwe bewaren. [The 'pocket archive'. Sharing is the new way to archive]. Tijdschrift Volkskunde, 3, 287-298.

Broeders, D., \& Dijstelbloem, H. (2013). Dreaming of seamless borders: ICTs and the pre-emptive governance of mobility in Europe. Journal of Ethnic and Migration Studies, 39(8), 1201-1218.

Brooker, P., Barnett, J., \& Cribbin, T. (2016). Doing social media analytics. Big Data \& Society, $3(2), 1-12$.

Candidatu, L., Leurs, K., \& Ponzanesi, S. (2018, Forthcoming). Digital diasporas: Beyond the buzzword. Towards a relational understanding of mobility and connectivity. In R. Tsagarousianou \& J. Retis (Eds.), The handbook of diasporas, media, and culture. New Jersey: Wiley-Blackwell.

Christensen, M., \& Jansson, A. (2014). Complicit surveillance, interveillance, and the question of cosmopolitanism. New Media \& Society, 17(9), 1473-1491.

Dekker, R., Engbersen, G., Klaver, J., \& Vonk, H. (2018, Forthcoming). Smart refugees. How Syrian asylum migrants use social media information in migration decision making. In K. Leurs \& K. Smets (Eds.), Social media + society. Special issue on Forced migration and connectivity in(to) Europe.

Diminescu, D. (2008). The connected migrant: An epistemological manifesto. Social Science Information, 47(4), 565-579.

Donà, G. (2014). Forced migration, and material and virtual mobility among Rwandan children and young people. In A. Veale \& G. Donà (Eds.), Child and youth migration. Mobility-inmigration in an era of globalization (pp. 116-139). New York: Palgrave.

Everett, A. (2009). Digital diaspora. A race for cyberspace. Albany: State University of New York Press.

Finaccord. (2014). Global expatriates. Size, segmentation and forecast for the worldwide market. http://finaccord.com/documents/rp_2013/report_prospectus_global_expatriates_size_segmentation_forecasts_worldwide_market.pdf. Accessed 20 June 2017.

Frouws, B., Phillips, M., Hassan, A., \& Twigt M. (2016). Getting to Europe the whatsapp way: The use of ICT in contemporary mixed migration flows to Europe (Briefing Paper 2). Danish Refugee Council. Regional Mixed Migration Secretariat. http://www.regionalmms.org/images/ briefing/Social_Media_in_Mixed_Migration.pdf. Accessed 20 June 2017.

Gajjala, R. (2004). Cyber selves: Feminist ethnographies of South Asian women. Walnut Creek: AltaMira Press.

Georgiou, M. (2006). Diaspora, identity and the media. Creskill: Hampton Press.

Gillespie, M., Ampofo, L., Cheesman, M., Faith, B., Illiadou, E., Issa, A., Osseiran, S., \& Skleparis, D. (2016). Mapping refugee media journeys. Research report. Open University/France Médias Monde. http://www.open.ac.uk/ccig/research/projects/mapping-refugee-media-journeys. Accessed 20 June 2017.

Gordano Peile, C. (2013). Mobile phones in migrant contexts: Commercial discourses and migrants' appropriations of ICT in Spain. O 429517 BS* Observatorio, special issue Media, technology and the migrant family (pp. 129-151).

Gregory, K., McMillan Cottom, T., \& Daniels, J. (2017). Introduction. In J. Daniels, K. Gregory, \& T. McMillan Cottom (Eds.), Digital sociologies (pp. xvii-xxxx). Bristol: Policy Press.

Halfpenny, P., \& Proctor, R. (2015). Innovations in digital research methods. London: Sage.

Hepp, A., Bozdag, C., \& Suna, L. (2011). Mediale migranten [Mediatized migrants]. Wiesbaden: VS Verlag.

Hine, C. (2015). Ethnography for the internet. London: Bloomsbury.

Horst, H., \& Miller, D. (2005). From kinship to link-up: Cell phones and social networking in Jamaica. Current Anthropology, 45(5), 755-778.

IOM. (2018) Migration flows Europe. International Organization for Migration. http://migration. iom.int/europe/. Accessed 13 March 2018. 
Koinova, M. (2010). Diasporas and international politics: Utilizing the universalistic creed of liberalism for particularistic and nationalist purposes. In R. Baubock \& T. Faist (Eds.), Diaspora and transnationalism (pp. 149-166). Amsterdam: Amsterdam University Press.

Kok, S., \& Rogers, R. (2017). Rethinking migration in the digital age: Transglocalization and the Somali diaspora. Global Networks, 17(1), 23-46.

Leurs, K. (2017). Feminist data analysis. Using digital methods for ethical, reflexive and situated socio-cultural research. Feminist Research, 115(1), 130-154.

Leurs, K., Ponzanesi, P. (2018) Connected migrants: Encapsulation and cosmopolitanization. Popular Communication, 16(1), 4-20.

Leurs, K., \& Shepherd, T. (2017). Datafication and discrimination. In K. van Es \& M. Schäfer (Eds.), The datafied society. Studying culture through data (pp. 211-234). Amsterdam: Amsterdam University Press.

Leurs, K. \& Smets, K. (2018). Five questions for digital migration studies: Learning from digital connectivity and forced migration in(to) Europe. Social Media + Society, 1-16. Advance Online Publication. https://doi.org/10.1177/2056305118764425.

Losh, E. (2015, June 22). The MOOC moment: Experiments in scale and access in higher education (\#FutureU workshop). Leuphana University Luneberg. http://de.slideshare.net/leuphanadigital/losh-leuphana. Accessed 20 June 2017.

Madianou, M., \& Miller, D. (2012). Migration and new media: Transnational families and polymedia. New York: Routledge.

Markham, A. (1998). Life online. Researching real experiences in virtual space. Walnut Creek: AltaMira Press.

McGregor, E., \& Siegel, M. (2013). Social media and migration research. United Nations University UNU-MERIT Working Papers 2013-068. www.merit.unu.edu/publications/ wppdf/2013/wp2013-068.pdf. Accessed 20 June 2017.

Messias, J., Benevenuto, F., Weber, I., \& Zagheni, E. (2016). From migration corridors to clusters: The value of Google + data for migration studies. In IEEE/ACM international conference on advances in social networks analysis and mining arXiv preprint arXiv:1607.00421. https:// arxiv.org/pdf/1607.00421v1.pdf. Accessed 20 June 2017.

Miller, D., \& Horst, H. (2012). The digital and the human. A prospectus for digital anthropology. In H. Horst \& D. Miller (Eds.), Digital anthropology (pp. 3-38). London: Berg.

Miller, D., \& Slater, D. (2000). The internet. An ethnographic approach. Oxford: Berg.

Moss, D. (2016). The ties that bind: Internet communication technologies, networked authoritarianism and 'voice' in the Syrian diaspora. Gobalizations. Early view. https://doi. org/10.1080/14747731.2016.12630791-18.

Naficy, H. (2007). Foreword: On the global inter-, multi-, and trans. In A. Grossman \& Á. O’Brien (Eds.), Projecting migration: Transcultural documentary practice (pp. Xiii-Xiiv). London: Wallflower Press.

O'Malley, J. (2015, September 7). Surprised that Syrian refugees have smartphones? The Independent. http://www.independent.co.uk/voices/comment/surprised-that-syrian-refugees-have-smartphones-wellsorry-to-break-this-to-you-but-youre-anidiot-10489719.html. Accessed 20 June 2017.

Oiarzabal, P., \& Reips, U. D. (2012). Migration and diaspora in the age of information and communication technologies. Journal of Ethnic and Migration Studies, 38(9), 1333-1338.

Pink, S., Horst, H., Postill, J., Hjorth, L., Lewis, T., \& Tacchi, J. (2016a). Digital ethnography. Principles and practice. London: Sage.

Pink, S., Markham, A., Akama, Y., Gómez Cruz, E., Lacasa, P., Poblet, M., \& Sumartojo, S. (2016b). Data ethnographies: Ethics and data futures. https://dataethnographies.com/paper-iiethics-and-data-futures/. Accessed 20 June 2017.

Ponzanesi, S., \& Leurs, K. (2014). On digital crossings in Europe. Crossings: Journal of Migration and Culture, 5(1), 3-22. https://doi.org/10.1386/cjmc.5.1.3_1.

Rogers, R. (2013). Digital methods. Cambridge: MIT Press. 
Sharma, S., \& Booker, P. (2017). \#notracist: Exploring racism denial talk on Twitter. In J. Daniels, K. Gregory, \& T. McMillan Cottom (Eds.), Digital sociologies (pp. 463-486). Bristol: Policy Press University of Bristol.

Smets, K. (2018, Forthcoming). Doing diasporic media research: methodological challenges and innovations In R. Tsagarousianou \& J. Retis (Eds.), The handbook of diasporas, media, and culture. New Jersey: Wiley-Blackwell.

Trimikliniotis, N., Parsanouglu, D., \& Tsianos, V. S. (2015). Mobile commons, migrant digitalities and the right to the city. Hampshire: Palgrave MacMillan.

Tronto, J. (1994). Moral boundaries: A political argument for an ethic of care. New York: Routledge.

UNCHR. (2016). Connecting refugees. How internet and mobile connectivity can improve refugee well-being and transform humanitarian action. United Nations Higher Commissioner of Refugees. http://www.unhcr.org/5770d43c4. Accessed 20 June 2017.

UNHCR. (2016). Global trends in forced displacement. United Nations Higher Commissioner of Refugees. http://www.unhcr.org/576408cd7. Accessed 20 June 2017.

Van Es, K., \& Schäfer, M. T. (Eds.). (2017). The datafied society. Studying culture through data. Amsterdam: Amsterdam University Press.

Wall, M., Campbell, M., \& Janbek, D. (2015). Syrian refugees and information precarity. New Media \& Society, Early view online.

WDR. (2016). My Escape/Meine Flucht. http://www1.wdr.de/mediathek/video/sendungen/wdrdok/video-my-escape-meine-flucht-100.html. Accessed 20 June 2017.

Zijlstra, J., \& Van Liempt, I. (2017). Smart(phone) travelling: Understanding the use and impact of mobile technology on irregular migration journeys. International Journal of Migration and Border Studies, 3(2-3), 174-191.

Open Access This chapter is licensed under the terms of the Creative Commons Attribution 4.0 International License (http://creativecommons.org/licenses/by/4.0/), which permits use, sharing, adaptation, distribution and reproduction in any medium or format, as long as you give appropriate credit to the original author(s) and the source, provide a link to the Creative Commons license and indicate if changes were made.

The images or other third party material in this chapter are included in the chapter's Creative Commons license, unless indicated otherwise in a credit line to the material. If material is not included in the chapter's Creative Commons license and your intended use is not permitted by statutory regulation or exceeds the permitted use, you will need to obtain permission directly from the copyright holder.

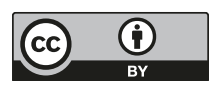

